\title{
ESTIMATION OF QUINOLONES, CEFTIOFUR AND THIAMPHENICOL RESIDUES LEVELS IN HONEY
}

\author{
IONELA DANIELA MORARIU ${ }^{1 \#}$, LILIANA AVASILCĂI ${ }^{1}$, MĂDĂLINA VIERIU ${ }^{1 \#}$, IONUT, \\ IULIAN LUNGU ${ }^{1}$, BRANCO MORARIU ${ }^{1 \#}$, SILVIA ROBU ${ }^{2}$, DANA TIUTUNARU ${ }^{2}$, OANA \\ CIOANCĂ $^{1 *}$, MONICA HĂNCIANU ${ }^{1}$ \\ I "Grigore T. Popa” University of Medicine and Pharmacy, Faculty of Pharmacy, 16 Universității Street, 700115, Iași, \\ Romania \\ ${ }^{2}$ Faculty of Medicine and Pharmacy, "Dunărea de Jos" University, 35 Al. I. Cuza Street, 800010 Galați, Romania
}

*corresponding author: oana.cioanca@umfiasi.ro

${ }^{\#}$ Authors with equal contribution.

Manuscript received: December 2020

\begin{abstract}
Quinolones, cephalosporins and amphenicols are antimicrobial agents effective in treating many infectious diseases caused by bacteria in both human and veterinary medicine. However, its residues in food products leads to increased bacterial resistance. Therefore, the quantification and limitation of such medicines should be verified through fast and reliable methods. The aim of the research was the simultaneous quantitative determination of quinolones, ceftiofur and thiamphenicol using biochip technology. The biochip method had excellent accuracy. The decision limit obtained for the analysed drugs was between 1.25 and $4.5 \mu \mathrm{g} / \mathrm{kg}$. The detection capacity recorded values in the range of $2.05-8.51 \mu \mathrm{g} / \mathrm{kg}$ for the analysed drugs. The recovery coefficient obtained was in the range of $77-123 \%$. The results of the analysis of Romanian honey samples using the biochip method were confirmed using a validated LC-MS/MS method.
\end{abstract}

\section{Rezumat}

Chinonolele, cefalosporinele şi amfenicolii sunt agenţi antimicrobieni eficienţi în tratarea a numeroase boli infecțioase cauzate de bacterii atât în medicina umană, cât și în cea veterinară. Totuși, reziduurile acestor compuşi în alimente conduce în timp la o rezistență bacetriană crescută. Prin urmare, cuantificarea și limitarea acestor medicamente ar trebui verificate prin metode rapide şi fiabile. Scopul cercetărilor a fost determinarea cantitativă simultană a chinolonelor, ceftiofurului şi tiamfenicolului folosind tehnologia biochip. Metoda biochip a avut o precizie excelentă. Limita de decizie obținută pentru substanțele analizate s-a încadrat între valorile 1,25 și $4,5 \mu \mathrm{g} / \mathrm{kg}$. Capacitatea de detecție a înregistrat valori pentru chimioterapicele determinate în intervalul 2,05 - 8,51 $\mu \mathrm{g} / \mathrm{kg}$. Coeficientul de recuperare obținut s-a situat în domeniul 77 $123 \%$. Rezultatele analizei probelor de miere românească folosind metoda biochip au fost confirmate printr-o metodă LCMS/MS validată.

Keywords: honey, quinolones, ceftiofur, thiamphenicol, biochip method

\section{Introduction}

The use of antibiotics in beekeeping is illegal in most EU countries. The maximum permitted limits for the antibiotic residues in honey have not been established in the European Community, which means that honey containing antibiotic residues cannot be marketed [11, 28].

Quinolones, cephalosporins and amphenicols are compounds commonly used for treating bacterial bee diseases $[1,3,23,29]$. The widespread use of such drugs in veterinary medicine represents a potential danger to human health. They can be present as residues in food $[25,27]$, which may cause allergic reactions or antibiotic resistance phenomena in humans [4, 22].

The quinolones mostly used as veterinary antimicrobial drugs are the fluoroquinolones $[6,7,8,20]$. Maximum residue limits (MRLs) have been established in different animal feed matrices for eight quinolones: marbofloxacin, ciprofloxacin, danofloxacin, enrofloxacin, sarafloxacin, difloxacin, flumequine and oxolinic acid $[2,5,11,30]$.

Ceftiofur is a third-generation cephalosporin, developed exclusively for veterinary use. It is bactericidal in vitro by inhibiting germ cell wall synthesis. Recently, ceftiofur has been used in beekeeping to treat bacterial infections [9, 16, 17]. Although it is not recommended during honey production, it has been detected in honey [14, 23].

Thiamphenicol is a broad-spectrum antibiotic, similar in structure and action mechanism to chloramphenicol [24]. Thiamphenicol is a broad-spectrum synthetic antibiotic that inhibits protein synthesis in the bacterial cell [21]. Thiamphenicol is used in beekeeping based 
on the bacteriostatic effect on various Gram-positive and Gram-negative bacteria [2, 18, 27].

Biochip Array Technology allows the simultaneous testing of multiple analytes from a single sample. It is one of the most rapid and cost-effective analysis methods $[2,12,13,19]$.

The research included the validation of a method for the simultaneous quantitative determination of some quinolones, cephalosporins (ceftiofur), amphenicols (thiamphenicol) using the biochip technology and analysis of quinolones, ceftiofur and thiamphenicol in various honey samples purchased from the Romanian market.

\section{Materials and Methods}

Biochip technology was used for the simultaneous, quantitative determination of of three representatives classes of antibiotics. The biochips contain three Discrete Test Regions, each of those regions corresponding to an antibiotic class. Each biochip incorporated a reference spot and a correction spot on its surface. In the image processing stage, the reference spot was located by the analyser software on a predefined $x$ and $y$ coordinates to validate the respective biochip. The correction spot was then used to define and locate the surface of each discrete test region.

Antimicrobial II panel was used to determine 3 types of antibiotics, namely, ceftiofur (CEFT), thiamphenicol (TAF) and generic quinolones (QNL).

All reagents were of analytical grade and the device manufacturer supplied it's in a compact kit that included Anti-Microbial Array II (EV3524) and Multianalit Control (AMC5004), both produced by Randox Laboratories from The United Kingdom.

Compared to conventional test systems, in which each separate test requires different reagents, for all determinations included in the Antimicrobial II panel, the Evidence Investigator system requires only two types of reagents. The volume of the used reagent for a test was lower than in any other system. The total required reaction volume was $350 \mu \mathrm{L}$. All reagents used had barcodes and applications that were downloaded to the analyser software automatically, from a CD included in the kit of each reagent batch, making the system easy to use.

The method of simultaneous quantitative determination using the biochip technology was validated following a protocol that simultaneously met the requirements of decision 2002/657/EC and the possibilities of any laboratory processing a large number of test samples [10].

The validation parameters evaluated were linearity, sensitivity, specificity, selectivity, accuracy, intermediate accuracy and reproducibility, the limit of detection and recovery.

To confirm the linearity of the method, a 9-point calibration was performed for each analyte using the standards included in the Antimicrobial Array II kit. The results obtained were automatically processed using the analyser software [15, 26].

The standards were supplied in a compact kit and the calibration curves were automatically generated by the dedicated analyser software. However, given the complex nature of the honey sample matrix, the calibration curves were also obtained using standards from the same matrix, which was a honey sample proven negative for drug residues using an LCMS/MS method, then spiked with the appropriate concentrations of the standards.

A standard multi-analyte solution was prepared. It contained $10 \mu \mathrm{g} / \mathrm{kg}$ of each analyte dissolved in methanol. Calibration curves were obtained by spiking the negative honey samples at 9 levels of concentration of the analytes: $0,0.001 \mu \mathrm{g} / \mathrm{kg}, 0.01 \mu \mathrm{g} / \mathrm{kg}, 0.05 \mu \mathrm{g} / \mathrm{kg}$, $0.1 \mu \mathrm{g} / \mathrm{kg}, 1 \mu \mathrm{g} / \mathrm{kg}, 4 \mu \mathrm{g} / \mathrm{kg}, 10 \mu \mathrm{g} / \mathrm{kg}$ and $50 \mu \mathrm{g} / \mathrm{kg}$. To evaluate the sensitivity of the method, IC50 was calculated for each analyte. IC50 represents $50 \%$ of the relative light unit (RLU) value corresponding to the zero concentration standards and extrapolating that RLU value from the $\mathrm{x}$-axis of the calibration curve on which the units of concentration were expressed as $\mu \mathrm{g} / \mathrm{kg}$. That concentration corresponded to the concentration, which produced $50 \%$ inhibition.

To determine the specificity and selectivity, known concentrations of each analyte were used in serial dilutions. Three replicates were analysed for each drug level in serial dilution to assign the percentage of cross-reactivity.

According to the validation guides, the percentage of cross-reactivity for drug residue determination in honey should not exceed $25 \%$ for concentrating the analytes at the minimum limit of quantification [13]. According to the current legislation and validation guides for the methods of determining the drug residues in honey, the accuracy and precision are evaluated for concentrations representing $50 \%, 100 \%$ and $150 \%$ respectively of the minimum required performance limit (MRPL) required for antibiotic residues in honey bees: MRPL $=1 \mu \mathrm{g} / \mathrm{kg}[15,26]$.

The accuracy within the same analytical series was determined by analysing 20 replicates of negative samples of honey that were spiked to achieve those 3 concentration levels of antibiotics.

The accuracy of different analytical series was determined by analysing 2 replicates of negative samples of honey that were spiked to achieve 3 concentration levels of antibiotics that were analysed during 10 working days. Accuracy and precision were acceptable if the coefficient of variation of the concentration in the control samples did not exceed $\pm 15 \%$ for all determinations executed during the same day.

To determine the decision limit $(\mathrm{CC} \alpha)$ and the detection capacity (CC $\beta$ ), 20 negative honey samples (blank samples) were selected. Aliquots of those samples were 
spiked with drugs at the target-screening concentration of $0.5 \mu \mathrm{g} / \mathrm{kg}$ for CEFT and TAF, and $1 \mu \mathrm{g} / \mathrm{kg}$ for QNL. The blank and spiked samples were tested. CC $\alpha$ was calculated as the average of the analyte concentration in the 20 samples spiked with the analyte concentration at MRPL level plus $1.64 \times$ standard deviation (SD) of repeatability at $\alpha=5 \%$. CC $\beta$ was calculated as the arithmetic average of the analyte concentration at $\mathrm{CC} \alpha$ plus $1.64 \times \mathrm{SD}$ of repeatability at $\alpha=5 \%$.

To estimate the recovery percentage, negative honey samples were used, spiked with the analytes at 3 different levels of concentration.

The validated biochip method was applied to 43 honey samples of different assortments for the determination of antibiotic residues. Honey samples analysed using an already validated LC-MS/MS method and identified as being drug-free were used as negative samples in the validation protocol [27]. Confirmation of the results obtained through the biochip method on the tested honey samples was done by the LC-MS/MS method [27]. The determinations were made using the Agilent 1100 LC system (Agilent Technologies, USA) coupled with the 4000 Q TRAP mass spectrometer (Applied Biosystems, USA).

The following parameters were followed to confirm the results: the signal/noise ratio selected for the characteristic ions was $>3$; differentiation of analyte retention time and the corresponding standard were $\pm 2.5 \%$; the deviation of the relative abundance of the characteristic ions of the target analyte and the deviation of the characteristic ions of the corresponding standard were between $\pm 20 \%$ and $\pm 50 \%$.

\section{Results and Discussion}

Nine biochips were used for calibration. The remaining 45 biochips were used for the control samples, to check the accuracy and precision within the same analytical series.

The calibration intervals were $0-7 \mu \mathrm{g} / \mathrm{kg}$ for QNL, $0-11.5 \mu \mathrm{g} / \mathrm{kg}$ for CEFT and $0-5 \mu \mathrm{g} / \mathrm{kg}$ TAF. The correlation coefficients (r) obtained for the drugs were in the range $0.982-0.998$, and the lowest coefficient was obtained for TAF.

The calculated IC50 were for each analyte $0.52 \mu \mathrm{g} / \mathrm{kg}$ for QNL, $0.25 \mu \mathrm{g} / \mathrm{kg}$ for CEFT and $0.5 \mu \mathrm{g} / \mathrm{kg}$ TAF. Specificity and selectivity were studies based on the cross-reactivity percentage that was determined against the parent compound and the corresponding chain of related compounds (Table I).

Table I

Cross-reactivity study results

\begin{tabular}{|l|c|c|c|l|c|c|c|}
\hline \multirow{2}{*}{ Cross-Reactant } & \multicolumn{2}{|c|}{ Cross-reactivity (\%) } & \multirow{2}{*}{ Cross-Reactant } & \multicolumn{3}{|c|}{ Cross-reactivity (\%) } \\
\cline { 6 - 9 } & QNL & CEFT & TAF & & QNL & CEFT & TAF \\
\hline Amoxicillin & & $<1$ & & Levofloxacin & 13 & & \\
\hline Ampicillin & & $<1$ & & Marbofloxacin & 16 & & \\
\hline Cefadroxil & & $<1$ & & Nadifloxacin & 14 & & \\
\hline Cefazolin & & $<1$ & & Nafcillin & & $<1$ & \\
\hline CEFT & $<1$ & 100 & $<1$ & Nalidixic acid & $<1$ & & \\
\hline Chlortetracycline & & $<1$ & $<1$ & Norfloxacin & 100 & $<1$ & $<1$ \\
\hline Cinoxacin & $<1$ & & & Ofloxacin & 21 & & \\
\hline Ciprofloxacin & 19 & & & Orbifloxacin & 11 & & \\
\hline Cloxacillin & & $<1$ & & Oxacillin & & $<1$ & \\
\hline Danofloxacin & 10 & & & Oxolinic acid & 12 & & \\
\hline Dicloxacillin & & $<1$ & & Pazufloxacin & 3 & & \\
\hline Difloxacin & 3 & & & Pefloxacin & 24 & & \\
\hline Enoxacin & 5 & & & Penicillin G & & $<1$ & \\
\hline Enrofloxacin & 8 & & & Pipemidic acid & 9 & & \\
\hline Fleroxacin & 12 & & & Sarafloxacin & 6 & & \\
\hline Florfenicol & & & 23 & Streptomycin & & $<1$ & $<1$ \\
\hline Florfenicol amine & & & $<1$ & TAF & $<1$ & $<1$ & 100 \\
\hline Flumequine & $<1$ & & & Ticarcillin & & $<1$ & \\
\hline Gatifloxacin & $<1$ & & & Tylosin & & $<1$ & $<1$ \\
\hline
\end{tabular}

Multianalyte Control (AMC 5004) produced by Randox Laboratories, UK was used to evaluate the accuracy and precision, and the average concentration and $\mathrm{CV} \%$ was calculated. The method presented excellent accuracy both within the same analytical series and in different analytical series (Table II), with typical values less than $15 \%$ for the determined concentrations.

The decision limit obtained for the classes of antibiotics determined was between $1.25 \mu \mathrm{g} / \mathrm{kg}$ and $5.5 \mu \mathrm{g} / \mathrm{kg}$. Also, the detection capacity obtained for the same drugs was between $2.05 \mu \mathrm{g} / \mathrm{kg}$ and $8.81 \mu \mathrm{g} / \mathrm{kg}$. The obtained values are presented in Table III. 
Table II

Precision and accuracy data

\begin{tabular}{|c|c|c|c|c|c|c|}
\hline \multirow{2}{*}{ Concentration } & \multicolumn{3}{|c|}{ Concentration $(\mu \mathrm{g} / \mathrm{kg})$} & \multicolumn{3}{|c|}{ CV (\%) } \\
\hline & CEFT & QNL & TAF & CEFT & QNL & TAF \\
\hline \multicolumn{7}{|l|}{ The same series } \\
\hline $0.5 \mu \mathrm{g} / \mathrm{kg}$ & 1.25 & 0.63 & 0.31 & 6.8 & 4.30 & 3.40 \\
\hline $1 \mu \mathrm{g} / \mathrm{kg}$ & 2.50 & 1.25 & 0.63 & 5.80 & 6.60 & 4.50 \\
\hline $2 \mu \mathrm{g} / \mathrm{kg}$ & 5.00 & 2.50 & 1.25 & 5.00 & 6.80 & 6.80 \\
\hline \multicolumn{7}{|l|}{ Different series } \\
\hline $0.5 \mu \mathrm{g} / \mathrm{kg}$ & 0.49 & 0.93 & 0.38 & 6.80 & 4.30 & 3.40 \\
\hline $1 \mu \mathrm{g} / \mathrm{kg}$ & 1.05 & 1.80 & 0.59 & 5.80 & 6.60 & 4.50 \\
\hline $2 \mu \mathrm{g} / \mathrm{kg}$ & 1.97 & 3.29 & 1.17 & 5.00 & 6.80 & 6.80 \\
\hline
\end{tabular}

Table III

Decision limit and detection capacity

\begin{tabular}{|l|c|c|c|}
\hline \multicolumn{1}{|c|}{ Validation parameters } & CEFT & QNL & TAF \\
\hline Average concentration $(\mu \mathrm{g} / \mathrm{kg})$ & 0.49 & 0.93 & 0.38 \\
\hline Standard deviation $(\mathrm{SD})$ & 2.44 & 1.52 & 0.53 \\
\hline $1.64 \times \mathrm{DS}$ & 4.01 & 2.50 & 0.87 \\
\hline $\mathrm{CC} \alpha(\mu \mathrm{g} / \mathrm{kg})$ & 4.50 & 3.43 & 1.25 \\
\hline $\mathrm{CC} \beta(\mu \mathrm{g} / \mathrm{kg})$ & 8.51 & 5.93 & 2.05 \\
\hline
\end{tabular}

Each spiked sample was then analysed and the recovery percentage was calculated using the formula:
Recovery $(\%)=((\mathrm{A}-\mathrm{B}) / \mathrm{C}) \times 100$, where: $\mathrm{A}$ was the average concentration determined for the analyte, $\mathrm{B}$ was the average analyte concentration in the sample and $\mathrm{C}$ was the analyte concentration in the spiked sample.

The recovery rates for honey samples can be found in Table IV. A recovery percentage $>70 \%$ required for each analyte was achieved with values in the range of $77-125 \%$.

\begin{tabular}{|c|c|c|c|c|c|c|}
\hline \multirow{2}{*}{ Concentration } & \multicolumn{3}{|c|}{ Analysed Concentration $(\boldsymbol{\mu g} / \mathbf{k g})$} & \multicolumn{3}{|c|}{ Recovery (\%) } \\
\cline { 2 - 7 } & CEFT & QNL & TAF & CEFT & QNL & TAF \\
\hline $0.5 \mu \mathrm{g} / \mathrm{kg}$ & 0.56 & 0.62 & 0.60 & 112 & 123 & 119 \\
\hline $1 \mu \mathrm{g} / \mathrm{kg}$ & 0.87 & 1.00 & 1.00 & 87 & 100 & 100 \\
\hline $2 \mu \mathrm{g} / \mathrm{kg}$ & 1.54 & 1.74 & 1.98 & 77 & 87 & 99 \\
\hline
\end{tabular}

Table IV

Recovery data

Table V

Comparison of the results obtained using the biochip method versus the LC-MS/MS method

\begin{tabular}{|c|c|c|c|c|}
\hline Sample No. & Method & QNL $(\boldsymbol{\mu g} / \mathbf{k g})$ & CEFT $(\boldsymbol{\mu g} / \mathrm{kg})$ & TAF $(\boldsymbol{\mu g} / \mathbf{k g})$ \\
\hline \multirow{3}{*}{1} & biochip & 10.4 & $<$ LOD & $<$ LOD \\
\cline { 2 - 5 } & LC-MS/MS & $\begin{array}{c}\text { Ciprofloxacin } 5 \mu \mathrm{g} / \mathrm{kg} \\
\text { Norfloxacin } 7 \mu \mathrm{g} / \mathrm{kg}\end{array}$ & $<$ LOD & $<$ LOD \\
\hline \multirow{3}{*}{2} & biochip & 54.9 & $<$ LOD & $<$ LOD \\
\cline { 2 - 5 } & LC-MS/MS & $\begin{array}{c}\text { Ciprofloxacin } 41 \mu \mathrm{g} / \mathrm{kg} \\
\text { Norfloxacin } 10 \mu \mathrm{g} / \mathrm{kg}\end{array}$ & $<$ LOD & $<$ LOD \\
\hline \multirow{3}{*}{3} & biochip & 12.7 & $<$ LOD & $<$ LOD \\
\cline { 2 - 6 } & LC-MS/MS & $\begin{array}{c}\text { Ciprofloxacin } 4 \mu \mathrm{g} / \mathrm{kg} \\
\text { Norfloxacin } 2 \mu \mathrm{g} / \mathrm{kg}\end{array}$ & $<$ LOD & $<$ LOD \\
\hline \multirow{3}{*}{4} & biochip & 11.4 & $<$ LOD & $<$ LOD \\
\cline { 2 - 6 } & LC-MS/MS & $\begin{array}{c}\text { Ciprofloxacin } 7 \mu \mathrm{g} / \mathrm{kg} \\
\text { Norfloxacin } 3 \mu \mathrm{g} / \mathrm{kg}\end{array}$ & $<$ LOD & $<$ LOD \\
\hline \multirow{2}{*}{5} & biochip & 9.4 & $<$ LOD & $<$ LOD \\
\cline { 2 - 6 } & LC-MS/MS & $\begin{array}{c}\text { Ciprofloxacin } 6 \mu \mathrm{g} / \mathrm{kg} \\
\text { Norfloxacin } 4 \mu \mathrm{g} / \mathrm{kg}\end{array}$ & $<$ LOD & $<$ LOD \\
\hline \multirow{2}{*}{6} & biochip & 24.6 & $<$ LOD & $<$ LOD \\
\cline { 2 - 6 } & LC-MS/MS & $\begin{array}{c}\text { Ciprofloxacin } 3 \mu \mathrm{g} / \mathrm{kg} \\
\text { Norfloxacin } 15 \mu \mathrm{g} / \mathrm{kg}\end{array}$ & $<$ LOD & $<$ LOD \\
\hline
\end{tabular}

After testing 43 honey samples, only residues of QNL were quantified in 6 samples. Both positive and negative samples were confirmed by the LC-MS/MS method. As can be seen from the data presented in Table V, the concentration values obtained using the biochip method are comparable to those obtained from the LC-MS/MS method. Following the application of the LC-MS/MS method, the samples having drug concentration greater than $1 \mu \mathrm{g} / \mathrm{kg}$ were confirmed to be positive.

The results of the 6 positive samples identified by the biochip method and confirmed by the LC-MS/MS 
method revealed the same QNL at concentration levels above MRPL, namely: ciprofloxacin and norfloxacin. Private beekeepers from different geographical regions in Romania provided the 6 QNL-positive samples of honey. The results obtained in the study were comparable to those previously published by other research teams in the scientific literature [16, 23].

As a result of the current study, we were able to confirm that the biochip method was suitable for the proposed purpose. The performances of the biochip method were adequate, and the results obtained were similar to the concentration values determined using the confirmatory method, for both positive and negative samples.

\section{Conclusions}

In terms of analytical performance, the biochip method presented excellent accuracy both within the same analytical series and in different analytical series, with typical values less than $15 \%$ for concentrations of $0.5,1$ and $1.50 \mu \mathrm{g} / \mathrm{kg}$. The decision limit was between $1.25 \mu \mathrm{g} / \mathrm{kg}$ and $4.5 \mu \mathrm{g} / \mathrm{kg}$. The detection capacity recorded values in the range of $2.05-8.51$ $\mu \mathrm{g} / \mathrm{kg}$. The recovery coefficient obtained was in the range of 77 - 125\% compared to the initial concentration. The method validation criteria (specificity, accuracy, linearity, limits of detection and quantification) complied with the recommendations of European Commission Decision 2002/657/EC and proved that the method can detect and quantify drug residues, without necessarily having to be tested by mass spectrometry or derivatization for fluorescence analysis of analytes. The immunological method proposed in our study presented the advantage that it did not require extraction of antibiotics from the biological matrix with organic solvents, as well as the advantage of obtaining a large number of results in a short time. Instrumental methods, such as LC/MS are sensitive and specific, are suitable for confirmation, but would be too laborious for screening a large number of samples.

The validation and application of the biochip method highlighted the fact that the Evidence Investigator System and the Antimicrobial Panel II represent an efficient system for the simultaneous detection and quantification of multi-analytes in honey samples. A comparison of the results obtained by the biochip method and the LC-MS/MS method revealed that the proposed biosensor method is suitable for the proposed purpose, namely, the determination of the concentration of each analyte during European food safety monitoring programs.

\section{Conflict of interest}

The authors declare no conflict of interest.

\section{References}

1. Alechaga É, Moyano E, Galceran MT, Ultra-high performance liquid chromatography-tandem mass spectrometry for the analysis of phenicol drugs and florfenicol-amine in foods. Analyst., 2012; 137(10): 2486-2494.

2. Bargańska Z, Slebioda M, Namiesnik J, Determination of antibiotic residues in honey. Trend Anal Chem., 2011; 30(7): 1035-1041.

3. Barrasso R, Bonerba E, Savarino AE, Ceci E, Bozzo G, Tantillo G, Simultaneous Quantitative Detection of Six Families of Antibiotics in Honey Using A Biochip Multi-Array Technology. Vet Sci., 2018; 6(1): E1.

4. Bogdanov S, Contaminants of bee products. Apidologie, 2006; 37: 1-18.

5. Bogdanov S, Current state of analytical methods for the detection of residues in bee products. Apiacta, 2003; 38: 399-409.

6. Boroni M, Tateo F, Liquid chromatography/tandem mass spectrometry analysis of chloramphenicol in propolis extracts available on the Italian market. $J$ Food Compos Anal., 2008; 21: 84-89.

7. Chen H, Chen H, Ying J, Huang J, Liao L, Dispersive liquid-liquid microextraction followed by highperformance liquid chromatography as an efficient and sensitive techinique for simultaneous determination of chloramphenicol and thiamphenicol in honey. Anal Chim Acta., 2009; 632: 80-85.

8. Chen L, Huang X, Sensitive Monitoring of Fluoroquinolones in Milk and Honey Using Multiple Monolithic Fiber Solid-Phase Microextraction Coupled to Liquid Chromatography Tandem Mass Spectrometry. J Agric Food Chem., 2016; 64(45): 8684-8693.

9. Chico J, Rúbies A, Centrich F, Companyó R, Prat MD, Granados M, Hight-throughput multiclass method for antibiotic residue analysis by liquid chromatographytandem mass spectrometry. J Chromatogr A, 2008; 1213: 189-199.

10. Commission Decision 2002/657/EC of 12 August 2002 implementing Council Directive 96/23/EC concerning the performance of analytical methods and the interpretation of results (Text with EEA relevance) (notified under document number $\mathrm{C}(2002)$ 3044). OJEU, 2002; L 221: 8-36.

11. Commission Regulation (EU) No $37 / 2010$ of 22 December 2009 on pharmacologically active substances and their classification regarding maximum residue limits in foodstuffs of animal origin. OJEU, 2011; L15: 1-72.

12. Fitzgerald SP, Lamont JV, McConnell RI, Benchikh E, Development of a High-Throughput Automated Analyzer Using Biochip Array Technology. Clin Chem., 2005; 51: 1165-1176.

13. Gaudin V, Hedou C, Soumet C, Verdon E, Evaluation and validation of a multi-residue method based on biochip technology for the simultaneous screening of six families of antibiotics in muscle and aquaculture products. Food Addit Contam Part A Chem Anal Control Expo Risk Assess., 2016; 33(3): 403-419.

14. Gentili A, Perret D, Marchese S, Liquid chromatographytandem mass spectrometry for performing confirmatory 
analysis of veterinary drugs in animal-food products. Trend Anal Chem., 2005; 24(7): 704-733.

15. Guidance for the Validation of Analytical Methods Used in Residue Depletion Studies VICH GL49, U.S. Department of Health and Human Services Food and Drug, Administration Center for Veterinary Medicine, April 9, 2010.

16. Hammel YA, Mohamed R, Gremaud E, LeBreton $\mathrm{MH}$, Guy PA, Multi-screening approach to monitor and quantify 42 antibiotic residues in honey by liquid chromatography-tandem mass spectrometry. J Chromatogr A, 2008; 1177: 58-76.

17. Hornish RE, Kotarski SF, Cephalosporins in veterinary medicine - ceftiofur use in food animals. Curr Top Med Chem., 2002; 2(7): 717-731.

18. Hu L, Zuo P, Ye BC, Multicomponent mesofluidic system for the detection of veterinary drug residues based on competitive immunoassay. Anal Biochem., 2010; 405: 89-95.

19. Lee YJ, Choi JH, Abd El-Aty AM, Chung HS, Lee HS, Kim SW, Rahman MM, Park BJ, Kim JE, Shin HC, Shim JH, Development of a single-run analytical method for the detection of ten multiclass emerging contaminants in agricultural soil using an acetatebuffered QuEChERS method coupled with LCMS/MS. J Sep Sci., 2017; 40(2): 415-423.

20. Lei H, Guo J, Lv Z, Zhu X, Xue X, Wu L, Cao W, Simultaneous Determination of Nitroimidazoles and Quinolones in Honey by Modified QuEChERS and LC-MS/MS Analysis. Int J Anal Chem., 2018; 2018: 42714385: 1-12.

21. Lombardo-Agüí M, García-Compaña AM, GámizGracia L, Cruces-Blanci C, Determination of quinolones use in bee products by ultra-high performance liquid chromatography-tandem mass spectrometry using a QuEChERS extraction procedure. Talanta, 2011; 93: 193-199.

22. Marinescu E, Elisei AM, Aprotosoaie AC, Cioancă O, Trifan A, Miron A, Robu S, Ifrim C, Hăncianu M, Assessment of heavy metals content in some medicinal plants and spices commonly used in Romania. Farmacia, 2020; 68(6): 1099-1105.
23. Michaaud V, Antibiotic residues in honey - the FEEDM view. Apiacta, 2005; 40: 52-54.

24. Morariu ID, Avasilcăi L, Vieriu M, Cioancă O, Hăncianu M, Immunochemical assay of chloramphenicol in honey. Farmacia, 2019; 67(2): 235-239.

25. Morariu ID, Avasilcai L, Vieriu M, Panainte AD, Bibire N, Novel Multiresidue Method for the Determination of Eight Trichothecene Mycotoxins in Pollen Samples Using QuEChERS-Based GCMS/MS. Rev Chim (Bucharest), 2017; 68(2): 304-306.

26. Morariu ID, Avasilcai L, Vieriu M, Panainte AD, Bibire N, Validation and Application of an Analysis Method of Four Metabolites of Nitrofurans in Honey. Rev Chim (Bucharest), 2018; 69(10): 2808-2812.

27. Moreno-Bondi MC, Marazuela MD, Herranz S, Rodriguez E, An overview of sample preparation procedures for LC-MS multiclass antibiotic determination in environmental and food samples. Anal Bioanal Chem., 2009; 395(4): 921-946.

28. Regulation (EC) No 470/2009 Of the European Parliament and of the Council of 6 May 2009 laying down Community procedures for the establishment of residue limits of pharmacologically active substances in foodstuffs of animal origin, repealing Council Regulation (EEC) No 2377/90 and amending Directive 2001/82/EC of the European Parliament and of the Council and Regulation (EC) No 726/2004 of the European Parliament and of the Council. OJEU, 2009, L 152: 11-22.

29. Vidal JL, Aguilera-Luiz MM, Romero-Gonzalez R, Garrido-Frenich A, Multiclass Analysis of Antibiotic Residues in Honey by Ultraperformance Liquid Chromatography-Tandem Mass Spectrometry. J Agr Food Chem., 2009; 57(5): 1760-1767.

30. Zhou J, Xue X, Chen F, Zhang J, Li Y, Wu L, Chen L, Zhao J, Simultaneous determination of seven fluoroquinolones in royal jelly by ultrasonic-assisted extraction and liquid chromatography with fluorescence detection. J Sep Sci., 2009; 32(7): 955-964. 